\title{
MARK 16:1-8: THE EMPTY TOMB OF A HERO?
}

\author{
Peter G. Bolt
}

Hamilton (using Bickermann) has suggested that in antiquity a Hero was proven to be such by means of an empty grave. This view, however, needs to be reevaluated in the light of the 'empty tombs' associated with Heroes and the 'tombs' associated with some of those reputed to have been translated. This evidence is compared to Mark's portrayal of Jesus' empty tomb to show that it is neither the empty tomb of a Hero, nor of one who has been translated (as has been contended), but of one who has been raised from the dead.

\section{Introduction}

The Greek Hero cults consisted of sacrifices offered at the grave of deceased human beings, in the belief that they were still active and able to exercise a powerful influence amongst those who still dwell under the sun. ${ }^{1}$ Heroes appear as beings worthy of worship alongside the gods, for the first time in about the year $620 \mathrm{BC}$, when Drakon committed the laws of his country to writing at Athens, ${ }^{2}$ although, presumably, he was enshrining a practice which was much older. The fact that Pausanias, in his description of his travels in the early second century, is still able to list a considerable number of such cults indicates that the Hero-cult was a persistent feature of Greek life for centuries.

As part of his argument that Mark constructed 16:1-8 upon the model of Hellenistic translation stories, N.Q. Hamilton claimed that 'a hero is recognised by the evidence of an empty grave'. ${ }^{3}$ Since his statement has been repeated by others as if true, it is worth closer attention.

\footnotetext{
1See E. Rohde, Psyche: The Cult of Souls and Belief in Immortality among the Greeks (London: Kegan Paul, Trench, Trubner, 1925) ch. 4; and L.R. Farnell, Greek Hero Cults and Ideas of Immortality (Oxford: Clarendon, 1921). 2Rohde, Psyche, 115, citing Porph. Abstr. 4.22.

${ }^{3}$ N.Q. Hamilton, 'Resurrection Tradition and the Composition of Mark', JBL 84 (1965) 418; repeated by W.L. Lane, The Gospel according to Mark (Grand Rapids: Eerdmans, 1974) 586, n. 11; R.H. Gundry, Mark: $A$
} 


\section{Bickermann's Contribution}

The classification of Mark 16:1-8 as a translation or 'removal' story ${ }^{4}$ goes back to the 1924 article by E. Bickermann, 5 which was initially put to rest fairly quickly 6 but has recently gained a more positive evaluation. However, Bickermann's form-critical work is not without its problems, and those who have cited him have accepted his assessment uncritically. ${ }^{7}$

Bickermann ${ }^{8}$ insisted that an empty grave was the sign of a translation, whereas the sign of a resurrection was not an empty tomb but the appearance of the one raised from the dead. On such reasoning, Mark 16:1-8 was constructed as a story of translation, not resurrection.

There are several problems with Bickermann's thesis. (1) The insistence that the two 'signs' are strictly indicative of either a translation or a resurrection no doubt carried more

Commentary on His Apology for the Cross (Grand Rapids: Eerdmans, 1993) 994.

4That is, where a person is removed 'from amongst men' and translated to another place, be it the Elysian fields, the Isles of the Blessed, amongst the gods, a subterranean abode, etc.

5E. Bickermann, 'Das leere Grab', ZNW 23 (1924) 281-291.

${ }^{6} \mathrm{Cf}$. W. Nauck: 'The conjecture of E. Bickermann...has found no approval' ('Die Bedeutung des leeren Grabes für den Glauben an den Auferstandenen', ZNW 47 (1956) 250 n. 40 (my translation). It received brief mention in a couple of German commentaries, but was ignored in English literature until Hamilton, who directly influenced Lane and Gundry.

${ }^{7}$ E.g. Hamilton, 'Resurrection Tradition'; Lane, Mark, 586 n. 11; Gundry, Mark, 994; R. Pesch, Das Markusevangelium. kap. 8,27-16,20 (Freiburg; Herder, 1977) 2.252, adding evidence from G. Lohfink, Die Himmelfahrt Jesu. Untersuchungen zu den Himmelfahrts- und Erhöhungstexten bei Lukas (Munich: Kösel-Verlag, 1971); A. Yarbro Collins, 'The Empty Tomb and Resurrection according to Mark', The Beginning of the Gospel: Probings of Mark in Context (Minneapolis: Fortress, 1992) 119-48; idem, 'Apotheosis and Resurrection', in P.B.S. Giversen (ed.), The New Testament and Hellenistic Judaism (Aarhus, Denmark: Aarhus UP, 1995) 88-100; M.A. Tolbert, Sowing the Gospel: Mark's World in Literary-Historical Perspective (Minneapolis: Fortress, 1989) 288 n. 30. Only H. Blackburn, Theios Anēr and the Markan Miracle Traditions. (Tübingen: Mohr [Siebeck], 1991) 234-38 rejects the notion that Mark was composed in the light of this Hellenistic literary motif (citing Bickermann and Hamilton) in favour of the historicity of the empty tomb traditions, but even he fails to question the validity of the arguments for that motif.

8Bickermann, 'Das leere Grab', $286 f f$. 
weight during the era of the form criticism, in which he operated, than it should today-although it should be noted that his assignment of Mark 16 to a 'translation' story did not even commend itself to Bultmann. ${ }^{9}$ (2) Bickermann's formcritical assessment of the various story-groupings, by which he hopes to isolate the characteristic features upon which he insists, tends unfortunately towards a fairly a-historical assessment of the material. Many of his examples are later than the NT, are clearly dependent upon its tradition, and therefore cannot help the reconstruction of the framework within which Mark's early readers would have understood his final chapter.10 (3) In order to maintain his dichotomy strictly, Bickermann does not fairly assess some of the evidence. 11 The concept of resurrection is only possible within a Jewish framework, and since it involves the coming out of the grave alive again, it implies both an empty grave and the potential for appearances. As such, both elements can be 'signs' of a

${ }^{9} \mathrm{R}$. Bultmann finds the essay 'highly instructive' but then fundamentally disagrees with it: '[Bickermann] rightly emphasises the contrast of the appearances of the risen Christ with the empty tomb, though he wrongly classes the latter among the "Removal" stories. But the story of the empty tomb is without any doubt not a "Removal Legend", but an apologetic Legend, as $\eta \gamma \varepsilon \dot{\rho} \theta \eta$ is meant to show, as is plain from Mk 16:6. It is erroneous to think that the empty tomb presupposes an immediate Ascension; the very opposite is the case, as the motif of the stone rolled away indicates' (History of the Synoptic Tradition [2nd ed.; Oxford: Blackwell, 1968] 290 n. 3).

${ }^{10} \mathrm{As}$ he turns to Mk. 16 in part 3, Bickermann talks of 'this usual proof' of a translation. But, up to this point, the article has only demonstrated the 'proof' by later material, mostly dependent upon the NT!

${ }^{11}$ Can the Lazarus story be regarded simply as an appearance story (Jn. 11:44), since it clearly contains the additional feature of an empty tomb, rather dramatically portrayed? Both elements happily co-exist in Gos. Nic. $17: 1$ - in the same verse! It seems entirely arbitrary, where both elements appear in the same text, to insist that this constitutes evidence of two distinct sources contaminating one another. Once again, such arguments were far more convincing previously, given the methodological stance of a bygone age, than they are today. Acts of Peter 28 hardly constitutes evidence of an appearance, since here it is a corpse which has not been buried that is in view, which is more analogous to the raising of Jairus' daughter from her bed, than it is to the raising of Jesus from the tomb. The Bride from Corinth has both elements; when the two witnesses (Rev. 11) stand on their feet, on Bickermann's criteria it seems to be more consistent with an appearance than a translation. 
resurrection having occurred-although there is nothing, of course, which compels the mention of both on every occasion.

\section{Hamilton's Heroes}

Bickermann's focus was upon the translation motif, and his few passing references to the Heroes were to those whose bodies could not be found and so were assumed to have been translated. It is not Bickermann who stated that 'a hero is declared such by evidence of an empty grave', but Hamilton, who then attempted to enlist E. Rohde's discussion of 'empty graves' as additional support.

In actual fact, Hamilton's statement has confused two motifs which should be kept quite distinct, namely, that of the translation-to-heaven (or wherever) motif, and that of the Hero. Although Mark 16:1-8 may have struck some chords for those readers familiar with such themes, the dissimilarity to both themes indicates that Mark utilises the empty tomb to present Jesus as neither a Hero, nor one who has been translated, but as one who has been raised from the dead.

\section{Jesus the Hero?}

\section{1. 'Empty Graves' and Heroes}

It was almost axiomatic in the ancient world that a dead person should be properly buried. Although the last act of contempt towards an enemy could be to leave them unburied, generally speaking such an act was a mark of disrespect; it was also dangerous, given the potential for the unburied to become vindictive ghosts.

The importance of providing a proper burial no doubt lies behind the practice of providing a cenotaph if the body was

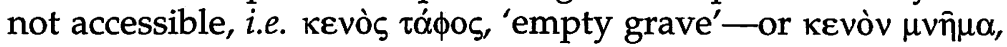

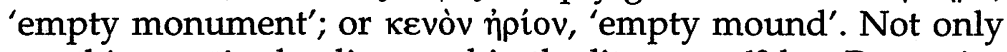
can this practice be discerned in the literature, ${ }^{12}$ but Pausanias

${ }_{12}$ Eurip. Helen 1057ff, 1546; Lycophron, Alex. 366; Xen. Anab. 6.4; Plut. 1130B (metaphorically). Rohde (Psyche, 42) also discerns it behind the practice of calling for dead comrades before leaving the country in which they fell; e.g. Od. 9.65-66. 
reports nine such cenotaphs, 13 and Dio Cassius one. ${ }^{14} \mathrm{~A}$ few have even survived, 15 and the Greek Anthology includes epitaphs from several more. ${ }^{16}$ This shows that, in order to honour the memory of someone who had fallen in a distant land or, especially, of someone lost at sea, 17 their survivors often erected an 'empty tomb'.

As well as 'empty tombs' being erected for ordinary people, they were sometimes associated with a Hero: e.g. Achilles (Paus. 6.23.3), the Argives who fought at Troy but died on the way home (Paus. 2.20.6), Teiresias (Paus. 9.18.4), Odysseus (Plut. QuaesGr. 48, 302C), and Kalchas (Lycoph. 1047f). Iolaos had a Heroshrine (i $\rho \hat{\omega} \circ v)$ and mound $(\chi \hat{\omega} \mu \alpha)$ at Thebes, even though the local citizens admitted he died at Sardis (Paus. 9.23.1).

Should the 'empty tomb' of Jesus be understood alongside the empty tombs of the ancient world? In the first place, since many were erected for 'mere mortals', as we have seen, it is clear that an 'empty tomb' would not automatically declare the one memorialised to be a Hero. More importantly, there is also a crucial difference between these 'empty tombs' and that of Mark 16.

\section{2. 'Empty Tombs' and Bodies}

In every case, an empty tomb clearly presupposes not only that the person has died (the significance of which will become clear later), but also that their body is elsewhere ${ }^{18}$-be it buried or unburied. This is evidently an important criterion for Pausanias, who not only indicates when a grave must be a cenotaph-since it is in one place, but the body is elsewhere (1.2.2) - but also reports his careful inquiries in order to

131.2.2 (Euripides); 2.20.6 (the Argives); 2.23.3 (Hyrnetho); 3.14.1 (Brasidas); 4.32.3 (Aristomenes); 6.20.16 (Myrtilus); 6.23.3 (Achilles); 9.18.4 (Teiresias); and 9.23.1 (Iolaos).

${ }^{14}$ For Drusus, on the Rhine; 55.2.3.

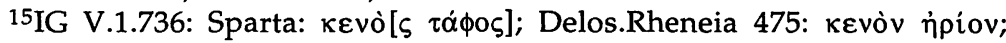

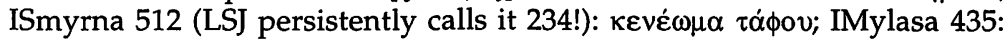

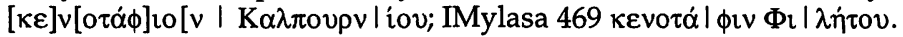

${ }_{16}$ AG 7.374, 395, 496, 497, 500.

17Delos.Rheneia 475; ?ISmyrna 512; $A G$ 7.374, 395, 496, 497, 500.

${ }^{18}$ Excluding such cases as $A G 8.229$, where it is used in a grave curse to express that the grave is empty of anything valuable, but only contains bones. 
determine whether or not a grave is 'occupied'. On one occasion he disbelieves the report that the grave contains Hyrnetho, and insists that it must be a cenotaph (2.23.3); on another he is surprised that it is not a cenotaph, but, upon inquiry, the locals inform him that they had acquired the bones of the occupant from Rhodes (4.32.3).

This is also true in the case of the 'empty tombs' associated with Hero cults. Rather than the Hero 'being recognised by the evidence of an empty grave', exactly the opposite was normally the case. Usually, the necessary prerequisite for a Hero-cult was the possession of his grave.

It is implied, as a rule,...that the grave contains the bones of the Hero. The bones-all that is left of his mortality-chain the Hero to his grave...The possession of the mortal remains of the Hero secured the possession of the Hero himself....As a rule, it is the remains of his former body that hold him fast. But these remains are a part of the Hero himself; though dead (and mummified, as we are told in one case: Hdt ix, 120), he works and acts just the same; his psyche, his invisible counterpart and double, hovers in the neighbourhood of the body and the grave. ${ }^{19}$

Because they were so important, the grave was at times kept secret for the protection of the remains. At other times, the bones of a Hero were brought from the place of his death to the place of his cult. However, since a grave fixes a Hero to a specific location, in cases where the remains were not accessible an 'empty tomb' 'sometimes had to do duty for a grave. In such cases the Hero was perhaps thought of as bound by a spell to that place'. ${ }^{20}$

In every case, the 'empty tomb' simply serves as a focal point for the Hero's cult, even though it is clearly known that the Hero's body is at some other physical location. Perhaps surprisingly, the 'empty tombs' (i.e. the cenotaphs) that were occasionally associated with the Hero cults have proven to be

\footnotetext{
${ }^{19}$ Rohde, Psyche, 122. Given his treatment of the evidence, it is surprising that the attempt has been made to enlist Rohde in support of the empty grave $=$ Hero thesis!

${ }^{20}$ Rohde, Psyche, 122. Hamilton ('Resurrection Tradition', 418) uses this quotation.
} 
evidence that, as a necessary condition of those cults, a body was needed in a grave!

This means that, if Jesus was going to be portrayed as a Hero, his body would have to remain in the tomb, or be known to be at some other physical location. Only this set of circumstances would be consistent with the (highly unlikely) speculation that there was some kind of Hero cult at Jesus' grave. ${ }^{21}$

\section{Jesus' Empty Tomb and his Body}

The evidence shows that the 'empty tomb' in the case of the Hero is nothing like that of Jesus according to Mark 16.

The appearance of the women characters in both scenes $(15: 40-47 ; 16: 1-8)$ ensures that the narrative presents the grave in which Jesus was buried as the same one which proves to be empty. The discussion regarding the removal of the stone $(16: 2-3)$, the report of its being removed (v. 4), the women's entrance into the tomb to discover the young man in white $(\mathrm{v}$. 5 ), leading to the first notice of the woman's alarm (v. 5; cf. v. 8)-all these provide an elaborate build-up to the announcement from one who presumably is regarded as a reliable commentator that the tomb is empty: 'he is not here' ( $\mathrm{v}$. 6). To reinforce that this was the tomb in which he should have been found, the young man adds: 'see the place where they laid him'. Mark's 'empty tomb' is no substitute for an absent body, but it is a tomb which used to contain a body, but does so no more.

The young man's statements focus attention on the empty tomb, but the announcement of Jesus' resurrection which precedes them is also highly significant. His body is no longer in this tomb, or in any other tomb: he is risen. ${ }^{22}$ The

${ }^{21}$ For a cult at the tomb, $c f$. the discussion in P. Perkins, Resurrection: New Testament Witness and Contemporary Reflection (London: Geoffrey Chapman, 1984) 93-94, 119, who agrees that there is no evidence for the veneration of the tomb. Cf. Gundry: 'Jewish Christians would have venerated the tomb had they thought it contained Jesus' remains. The lack of evidence that they did favours that from the start they knew it to be empty' [i.e., in a non-Hero sense!] (Mark, 995).

22Hamilton ('Resurrection Tradition', 419) ignored this announcement, and focused on the command to go to Galilee and on Jesus' epithet 'of Nazareth', in an attempt to draw a parallel with the Hero, whose sphere of influence was localised. In doing so, he missed the glaringly obvious 
announcement of Jesus' risen-ness raises the question whether Mark 16 should be understood against Greco-Roman notions of being translated.

\section{Translation?}

What of the 'Heroes' translated 'from amongst men', to another place? Were there some whose body did not remain in the grave?

\section{Normal Translations}

In the usual translation motif, the person is granted the privilege of avoiding death, which means that there is no mention of a grave, let alone an empty one. This is so for the Jewish translations of Enoch ${ }^{23}$ and Elijah. ${ }^{24}$ It is also the norm for Greco-Roman translations: Ganymede, 25 Herakles, ${ }^{26}$ Empedocles, ${ }^{27}$ Romulus, ${ }^{28}$ Semiramis, ${ }^{29}$ Aristeas, ${ }^{30}$ Euthymos, ${ }^{31}$ and Apollonius. ${ }^{32}$ It is also worth noting that the translated ones were not usually regarded as Heroes but, because they were immortalised, they were usually considered to have become gods (i.e. 'apotheosis'). 33

point that the Hero was localised at his tomb, and Jesus' tomb was near Jerusalem. Instead, the command (v. 7) is confirmation that he has risen.

${ }^{23}$ Gn. 5:24; 2 Ki 2:1-14; Sir. 44:16; 49:14; Heb. 11:5; 1 En. 70:1-4; 2 En. 1 et passim; 3 En. incipit; Vit. Proph. 21:15.

$242 \mathrm{Ki}$. 2; contrast Josephus' account of Moses, Jewish Ant. 4.326.

25Il. 20.232ff; Hdn. 1.11.2.

${ }^{26}$ Hes. Theog. 950ff; Pind. N.1, $61 \mathrm{ff}$.

27D.L. 8.68-69; although even his translation was disputed.

${ }^{28}$ E.g. Plut. Rom. 27-28.

${ }^{29}$ Diod. Sic. 2.14.3 and 20.1.

${ }^{30}$ Hdt. 4.14.

31Paus. 6.6.10.

32Philostr. VitAp. 8.31. Apparently coining his own word, Philostratus does not know of 'encountering either tomb or "false-tomb" ( $\tau \dot{\alpha} \phi \omega \mu \varepsilon \dot{\varepsilon} \nu \ddot{\eta}$ $\psi \varepsilon v \delta \circ \tau \alpha \phi i \omega . . . \pi \rho \circ \sigma \tau \chi \chi \omega ่ v)$ ' for Apollonius anywhere, even though he has travelled widely.

33Hamilton ('Resurrection Tradition', 418f) illustrates the tendency to move from apotheosis to Hero-isation, with no hint that the two concepts were different! Note, however, that the sources sometimes regard Herakles as a Hero and at other times as divine. 


\section{Translations with 'Tombs'}

There are, however, several exceptions to this norm in which Heroes were apparently translated after they died. Rohde observed that it was not considered a contradiction to erect cenotaphs, not only to those whose bodies were irrecoverable, but also to Heroes whose bodies had been translated'. ${ }^{34}$ In support, he cited only two stories: (1) The version of Achilles' end in the Aithiopis, in which he is snatched from the funeral pyre by Thetis; and (2) the story of Herakles in Diodorus Siculus, in which Herakles, after he has been struck by lightning and snatched up into the sky, has a mound $(\chi \hat{\omega} \mu \alpha)$ made for him, though no bones were found upon the pyre ( $\pi$ vó́).35

With regard to the first example, Rohde himself argues that the Aithiopis boldly introduces the idea of translation, but retains the reference to the mound 'evidently [as] a concession to the older narrative, which knew nothing of the translation of the body but gives prominence to the grave-mound' (cf. Od. $24.47 \mathrm{ff}$ ). The result is a confusion of motifs which should properly be distinguished from each other. The same confusion can be detected in the second account. If Mark constructed his account on the basis of some such precedent, then he has followed a confused template, and Mark 16 joins the ranks of this small group of stories which confuse the Hero with the translated.

But, in any case, these two exceptions have marked dissimilarities to Mark's account. In both, the body never made it to the grave, whereas Mark's story very clearly provides a proper burial for Jesus before emptying the grave of his body. In both stories, the translation happens at the moment of the funeral, and the mound is very clearly constructed after the translation, purely as a memorial-since all concerned are aware that the body is not there and never has been; accordingly, these stories are closely related to the other 'empty tombs' and, therefore, this increases the distance from Mark 16.

\footnotetext{
${ }^{34}$ Rohde, Psyche, 65 n. 29.

${ }^{35}$ Diod. Sic. $4.38 .5 ; 39.1$. The similarity of these two stories, in which there is a translation but also a grave-memorial, to the apotheosis of the Roman emperors is apparent. I have more to say about Mark's relationship with the notion of the apotheosis of the emperors in my Ph.D. thesis (currently being researched at King's College, London), but will not go into it here.
} 
Jesus rises after being placed dead in the tomb, on the third day, and he is raised from out of the tomb.

But this makes his case similar to two other exceptional stories.

\section{Translation from a 'Tomb'}

Kleomedes of Astypalaia was disqualified after killing his opponent in a boxing match at the 71st Olympic festival. Enraged, he returned home and tore down the pillar supporting the roof of a boys school, killing the boys. He fled to Athena's temple and hid in a chest. When it was broken open, he was not found inside it. The oracle informed the envoys that he had become a Hero- indeed, the last of the Heroes ${ }^{36}$ - and that he should be honoured with sacrifice (Paus. 6.9.6-7; Plut. Rom. 28). Although called a 'Hero', this is probably only in the later derivative sense, rather than being a true Hero of the Hero-cult. ${ }^{37} \mathrm{Be}$ that as it may, the significance of the story is its combination of the notion of Hero, with the ancient notion of translation of individual mortals who disappear without dying. 38

The stark difference from Mark 16 is obvious: Kleomedes does not die, and he has no grave. Rather than being an 'empty grave' story, this is clearly a variant upon the normal translation story.

The other story which can be considered a variant upon the translation theme is the incident in which the body of Alkmene disappears from the bier, and a stone substituted (e.g. Plut. Rom. 28.6-8). Here she has died, but never receives burial; her disappearance occurs before the event. It is also of interest that she had no tomb at all (Paus. 9.16.7); she 'receives divine honours' ( $\tau \mu \omega \hat{\omega} v$ i $\sigma 0 \theta \dot{\varepsilon} \omega v$ हैं $\chi \chi \varepsilon)$, rather than those as to a Hero. ${ }^{39}$

\footnotetext{
36Rohde comments wryly: 'indeed, it might well appear time to close at last the already over-lengthy list of "Heroes". The Delphic oracle had itself contributed largely to their increase, and with full intent; nor did it observe for long its own decision to make an end now' (Psyche, 130).

37Rohde: 'He could, however, only be called a "Hero" because there was no common name to describe the effect of translation which made men no longer mortals nor yet gods' (Psyche, 130).

${ }^{38}$ Rohde, Psyche, 129.

${ }^{39}$ In which case the language would be different; for example, the verb غंv $\alpha i \zeta \omega$ would be used. The two types of offerings ('as to a god', and 'as to a Hero') followed completely different procedures.
} 
In short, she does not seem to be a Hero, but she has been translated and experienced apotheosis; she has become a god.

In contrast, Jesus arises out of the tomb, in which he had been lying for the span of three days. The word $\eta \gamma \varepsilon \rho \theta \eta$, 'he is risen', does not fit a translation, 40 since the translation involved either the avoidance of death or at least one's removal at the point of the funeral. Instead, Mark clearly shows Jesus dying and being buried, with the clear intention of being raised from death. According to Mark's presentation, Jesus has already refused the opportunity of an apotheosis (along the more normal lines), when he came down the mountain of transfiguration (Mk. 9:2-13). Mark 16 does not describe an apotheosis; it was a resurrection from the dead.

\section{Jesus the Hero?}

Mark 16:1-8 may well grab the attention of a reader attuned to the usually quite separate notions of the Hero cult and of translation. However, such a reader would also notice the very clear differences in Mark's account. Jesus' genuinely empty tomb (i.e. empt-ied tomb) prevents him from being regarded as a Hero. The fact that he died, and was buried for some time, ensures that he genuinely joined the dead, and was not given the luxury of a translation away from death. Mark does not provide Jesus with an apotheosis, but the narrative insists that the Jesus 'who was crucified' experienced resurrection: 'He is risen. He is not here.'

This is no Hero's tomb; nor is it the tomb of some fortunate who has found a way around death for himself and himself alone. This tomb is that of the Son of Man, whose emptied tomb is pregnant with hope for the many.

\footnotetext{
${ }^{40}$ Noted even by Bickermann, 'Das leere Grab', 286. Narratives used a range of language to refer to translations, e.g. the notion of disappearing, or becoming invisible, ( $\left.\dot{\alpha} \phi \alpha v i \zeta_{-}\right)$is frequent; if divinisation was involved, the $\dot{\alpha} \pi \circ \theta \varepsilon \omega \sigma-$ or $\dot{\varepsilon} \kappa \theta \varepsilon \mathrm{l}-$ groups could be used; phrases expressing the changed location also occur ('from amongst men' / 'to amongst the gods').
} 